\title{
Мультидисциплінарний підхід до хірургічного лікування феохромоцитоми наднирників
}

\author{
А. В. Скумс, О. М. Гулько, В. А. Кондратюк, О. М. Симонов
}

Національний інститут хірургії та трансплантології імені О. О. Шалімова НАМН України, м. Київ

\section{Multidisciplinary approach in surgical treatment of the suprarenal gland pheochromocytoma}

\author{
A. V. Skums, O. M. Gulko, B. A. Kondratiuk, O. M. Symonov \\ Shalimov National Institute of Surgery and Transplantology, Kyiv
}

\section{Реферат}

Мета. Оцінити результати застосування мультидисциплінарного підходу в лікуванні феохромоцитоми наднирників. Матеріали і методи. Для аналізу ефективності схеми періопераційного лікування проспективно та ретроспективно досліджено результати лапароскопічної адреналектомії (ЛА), виконаної з приводу феохромоцитоми у 31 хворого за період з 2015 по 2017 р. Пацієнтів розподілили на дві групи: 1-ша - 15 хворих, яким періопераційне лікування проводили із застосуванням мультидисциплінарного підходу, 2-га - 16 пацієнтів, яким виконали тільки ЛА. Аналізували середню тривалість оперативного втручання, середній об'єм інтраопераційної крововтрати, геодинамічні показники та ускладнення. Результати. Середній об’ем інтраопераційної крововтрати у 1 -й групі становив $(48,7 \pm 9,1)$ мл, у 2 -й - $(231,3 \pm 113,8)$ мл ( $<<0,05)$, середній рівень метанефрину в сечі до адреналектомії - відповідно $(290,9 \pm 71,8)$ та $(991,2 \pm 703,0)$ мкг/добу $(\mathrm{p}<0,05)$. Середня тривалість оперативного втручання у паціентів $1-$ гі групи становила $(117,7 \pm 52,1)$ хв і була несуттево меншою порівняно з пацієнтами $2-і$ групи - $(164,7 \pm 57,5)$ хв ( $=0,133)$. Гемодинамічну нестабільність спостерігали лише у 5 пацієнтів $2-і ̈$ групи. Середні строки лікування після операції пацієнтів $1-і ̈$ групи становили $(5,9 \pm 2,2)$ дня, $2-$-ї - $(11,3 \pm 5,4)$ дня $(\mathrm{p}<0,05)$. Ускладнення виникли у $2(12,5 \%)$ пацієнтів $2-і$ групи. Ніхто із пацієнтів обох груп не помер. Висновки. У паціентів з феохромоцитомою наднирника періопераційне лікування із застосуванням мультидисциплінарного підходу є більш безпечним й ефективним та менш тривалим у порівнянні з виконанням тільки ЛА.

ключові слова: феохромоцитома; лапароскопія; мультидисциплінарний підхід; адреналектомія; гемодинамічна нестабільність

\section{Abstract}

Objective. To estimate the results of the multidisciplinary approach application in treatment of the suprarenal gland pheochromocytoma.

Materials and methods. Results of laparoscopic adrenalectomy (LA), performed for pheochromocytoma in 31 patients in 2015 - 2017 yrs, were investigated prospectively and retrospectively for analysis of efficacy of the perioperative treatment scheme. The patients were divided into two Groups: Group I - 15 patients, in whom perioperative treatment was conducted, using multidisciplinary approach, and Group II - 16 patients, in whom LA was conducted only. Median time of the operative intervention conduction, average volume of intraoperative blood loss, hemodynamical indices and complications are analyzed.

Results. Average volume of intraoperative blood loss in the Group I have constituted $(48.7 \pm 9.1) \mathrm{ml}$, in the Group II - (231.3 \pm $113.8) \mathrm{ml}(\mathrm{p}<0.05)$, median level of metanephrine in urine before adrenalectomy - accordingly, - (290.9 \pm 71.8$)$ and (991.2 \pm $703.0) \mathrm{mcg} /$ day $(\mathrm{p}<0.05)$. Median duration of operative treatment in the group I patients have constituted $(117.7 \pm 52.1) \mathrm{min}$ and was nonessentially lesser, comparing with the Group II patients - $(164.7 \pm 57.5) \min (\mathrm{p}=0.133)$. Hemodynamical instability was observed in 5 patients of Group II only. Median terms of postoperative treatment in the Group I patients have constituted $(5.9 \pm 2,2)$ days, and in Group II - $(11.3 \pm 5.4)$ days $(\mathrm{p}<0.05)$. Complications have occurred in $2(12.5 \%)$ patients of Group II. All the patients of Groups I-II have survived the treatment.

Conclusion. In patients with suprarenal gland pheochromocytoma a perioperative treatment, using multidisciplinary approach, is safe, effective and less durable, comparing with the LA conduction only.

Keywords: pheochromocytoma; laparoscopy; multidisciplinary approach; adrenalectomy; hemodynamical instability.

Феохромоцитома - гормонально-активна пухлина, яка у 80 - 85\% спостережень виникає з хромафінних клітин мозкової речовини надниркових залоз та секретує у підвищеній кількості катехоламіни [1]. Єдиним методом радикального лікування феохромоцитоми є їі оперативне видалення [1].

3 огляду на патофізіологічні особливості феохромоцитоми, їі мобілізація під час операції може призвести до різкої зміни рівня катехоламіну і, як наслідок, виражених коливань артеріального тиску [2, 3]. Незважаючи на передопераційну медикаментозну підготовку, одним з основних ускладнень під час видалення феохромоци- томи наднирника залишається синдром некерованої гемодинаміки (СНГ), який виникає у 10,3\% пацієнтів [4, 5].

ЛА вважають операцією вибору та застосовують у 66,4 - 79,2\% пацієнтів з пухлинами наднирників [6]. Сдиним конкретним протипоказанням для цієї операції є рентгенологічно доведена пухлинна інвазія в суміжні органи і магістральні судини [2, 6, 7]. Доведено переваги ЛА, але створення пневмоперитонеуму і мобілізація надниркової залози можуть спричинити гіпертонічний криз, а видалення самої пухлини призвести до стійкої гіпотонії або навіть шоку [3]. Рання перев'язка центральної вени наднирника (ЦВН) є ключовим фактором зниження ризи- 
ку надмірного викиду гормонів надниркової залози, але це не завжди можливо, особливо коли розміри новоутворень перевищують 6 см.

Мета дослідження: оцінити результати застосування мультидисциплінарного підходу в лікуванні феохромоцитоми наднирника.

\section{Матеріал і методи дослідження}

За 2015 - 2017 рр. у відділенні хірургії поєднаної патології і захворювань заочеревинного простору Інституту мультидисциплінарний підхід застосували у лікуванні 15 пацієнтів з феохромоцитомою наднирника (1-ша група). Для порівняльного аналізу відібрали 16 пацієнтів 3 феохромоцитомою наднирника, яким виконали тільки ЛА за період з 2008 по 2017 р. (2-га група).

Усім хворим проводили стандартне обстеження, що включало ультразвукове дослідження, комп'ютерну томографію (КТ) та магнітно-резонансну томографію (МРТ) черевної порожнини, загальну лабораторну діагностику, консультацію ендокринолога. Діагноз феохромоцитоми встановлювали на основі клінічної картини, біохімічних досліджень (рівень метанефрину і катехоламіну в сечі), а також патогномонічних рентгенологічних ознак - середня нативна щільність феохромоцитоми під час КТ становить 25 - 40 HU (Hounsfield units), під час MPТ на Т2-зважених зображеннях фіксується висока інтенсивність сигналу.

Усім хворим виконали передопераційну альфаадренергічну блокаду.

Мультидисциплінарний підхід полягав у послідовному виконанні рентгенендоваскулярної селективної електрокоагуляційної оклюзії (РЕВСЕО) вен і артерій наднирника та ЛА через 24 год. Метою ендоваскулярного втручання було зменшення ризику розвитку СНГ та виникнення кровотечі під час операції.

PEBCEО судин наднирника виконували в такий спосіб. В умовах рентгенопераційної трансфеморальним доступом катетеризували нижню порожнисту вену (НПВ) (катетер Terumo OPTITORQUE®, Cobra 2 (C2) RH-AB55108M. Fr.5 $1.7 \mathrm{~mm}$; L: 80cm; Tip curve L: Middle; side holes 0). Якщо цільовою була права ЦВН, ії знаходили на стінці НПВ справа на рівні XI, XII грудних хребців. Для пошуку лівої ЦВН катетер проводили спочатку в ліву ниркову вену, потім знаходили вустя лівої ЦВН по верхній стінці проксимальної третини ниркової вени. Після стійкої катетеризації гирла лівої ЦВН виконували флебографію ручним введенням 10

\begin{tabular}{|c|c|c|c|c|}
\hline \multicolumn{5}{|c|}{ Характеристика пацієнтів порівнюваних груп } \\
\hline \multirow{3}{*}{ Параметри } & \multicolumn{4}{|c|}{ Групи пацієнтів } \\
\hline & \multicolumn{2}{|c|}{ 1-ша $(n=15)$} & \multicolumn{2}{|c|}{2 -га $(n=16)$} \\
\hline & абс. & $\%$ & абс. & $\%$ \\
\hline \multicolumn{5}{|l|}{ Стать } \\
\hline чоловіки & 6 & 40 & 6 & 37,5 \\
\hline жінки & 9 & 60 & 10 & 62,5 \\
\hline Середній вік, роки & \multicolumn{2}{|c|}{$43,5 \pm 10,4$} & \multicolumn{2}{|c|}{$45 \pm 12,4$} \\
\hline \multicolumn{5}{|l|}{ Локалізація пухлин } \\
\hline справа & 10 & 66,7 & 9 & 56,3 \\
\hline зліва & 5 & 33,3 & 7 & 43,7 \\
\hline Розмір пухлин, см & \multicolumn{2}{|c|}{$6,7 \pm 1,8$} & \multicolumn{2}{|c|}{$5,9 \pm 2,9$} \\
\hline
\end{tabular}

мл неіонної трийодованої рентгеноконтрастної речовини. В просвіт ЦВН вводили електрод (EMERALD ${ }^{\text {TM }}$ Guidwire 502-542. 150cm, F0912186 2015-08), виконували PEBCEO ЦВН коагулятором (Söring Medizintechnick MBC 601 UAM 2012) у режимі «Coag Force $120 \mathrm{~W} 350 \mathrm{kHz}$ протягом 3 с тричі. Через 5 хв проводили контрольну флебографію та оцінювали ефективність виконаної РЕВСЕО. Після ангіографічного підтвердження оклюзії ЦВН катетер видаляли.

Коли діаметр ЦВН дорівнював 5 або 6 мм, для досягнення їі селективної оклюзії використовували електрокоагуляцію в комбінації з попередньою емболізацією мініатюрними сталевими спіралями.

Для візуалізації артерій наднирника трансфеморальним доступом катетеризували аорту (катетер Terumo OPTITORQUE®, Cobra 2 (C2) RH-AB55108M. Fr.5 1.7mm; L: $80 \mathrm{~cm}$; Tip curve L: Middle; side holes 0) та виконували аортографію. Після селективної катетеризації верхньої, середньої та нижньої надниркових артерій, що беруть початок від нижньої діафрагмальної артерії, аорти і ниркової артерії відповідно, виконували їх ангіографію, вводили в просвіт електрод (EMERALD ${ }^{\mathrm{TM}}$ Guidwire $502-542.150 \mathrm{~cm}$, F0912186 2015-08) та виконували РЕВCEО артерій наднирника через встановлений електрод коагулятором (Söring Medizintechnick MBC 601 UAM 2012) у режимі «Coag Force 120 W 350 kHz» протягом 3 с тричі. Через 5 хв виконували контрольну артеріографію. Після ангіографічного підтвердження оклюзіі артерій наднирника катетер видаляли.

ЛА виконували з латерального трансочеревинного доступу.

У групах хворих порівнювали гемодинамічні показники, тривалість оперативного втручання, розміри пухлин, об'єм інтраопераційної крововтрати та частоту ускладнень, які класифікували за шкалою Clavien-Dindo. СНГ визначали, коли систолічний артеріальний тиск (САТ) перевищував 26,7 кПа (200 мм рт. ст.), фіксували принаймні один епізод із САТ понад 26,7 кПа (200 мм рт. ст.); коли САТ був менше 10,7 кПа (80 мм рт. ст.), фіксували принаймні один епізод із САТ менше 10,7 кПа (80 мм рт. ст.); коли САТ, який перевищував 26,7 кПа (200 мм рт. ст.), Знижувався до рівня менше 10,7 кПа (80 мм рт. ст.) $[1,8]$.

Нормальний розподіл безперервних змінних аналізували, використовуючи тест Пірсона $\chi^{2}$. Змінні, які мали ненормальний розподіл, порівнювали з використанням U-критерію Манна-Уітні. Значення р менше 0,05 визначали як статистично значущі. Дані були внесені в таблиці Excel (Microsoft) і перетворені на базу даних SPSS (IBM). Статистичний аналіз проводили з використанням SPSS версії 23.0.

\section{Результати}

За віком, статтю, локалізацією пухлин, їх розміром суттєвої різниці між обома групами хворих не було (див. таблищя).

Під час РЕВСЕО у 6 (40\%) хворих 1-ї групи виявлена варіантна анатомія вен: у 5 - ЦВН і одна додаткова вена, що впадала в НПВ, у 1 - ЦВН і дві додаткові вени, що також впадали в НПВ. У разі збільшення розміру пухлини спостерігали не тільки варіантну анатомію вен, а й зміни діаметра самої ЦВН. Якщо розмір пухлини наднирника перевищував 8 см, діаметр ЦВН дорівнював або перевищував 5 
мм, у середньому становив $(5,6 \pm 0,8)$ мм. У таких пацієнтів для досягнення селективної оклюзії ЦВН використовували електрокоагуляцію в комбінації з попередньою емболізацією мініатюрними сталевими спіралями.

Із 15 пацієнтів 1-ї групи у 5 виконали РЕВСЕО верхньої, середньої та нижньої надниркових артерій, у 5 - верхньої та середньої, у 3 - верхньої та нижньої, у 1 - нижньої та ще у 1 - середньої надниркової артерії. Процедура тривала $20-30$ хв.

На початковому етапі впровадження в практику мультидисциплінарного підходу після РЕВСЕО у 1 пацієнта під час ЛА була виявлена субкапсульна гематома наднирника, що не ускладнило виконання ЛА. У решти пацієнтів візуальних патологічних змін, пов'язаних з виконанням ендоваскулярного втручання, не було. У 2 пацієнтів у післяопераційному періоді виник больовий синдром, який зник після призначення ненаркотичних аналгетиків.

У пацієнтів 1-ї групи середній рівень метанефрину в сечі до та через 24 год після РЕВСЕО ЦВН становив $(1179,9 \pm$ $1072,5)$ та $(290,9 \pm 71,8)$ мкг/добу відповідно ( $=0,00067)$. У хворих 2-ї групи середній рівень метанефрину в сечі перед ЛА становив (991,2 \pm 703,0) мкг/добу (p=0,00073).

Тривалість оперативного втручання у 1 -й групі була меншою, але несуттєво - (117,7 $\pm 52,1)$ хв порівняно $3(164,7 \pm$ $57,5)$ хв у $2-$ й групі $(\mathrm{p}=0,133)$. Середній об'єм крововтрати достовірно був менший у 1 -й групі порівняно $32-ю$ - $(48,7 \pm 9,1)$ та $(231,3 \pm 113,8)$ мл відповідно $(\mathrm{p}=0,0006)$.

СНГ спостерігали у 5 пацієнтів 2-ї групи. У 2 (12,5\%) пацієнтів виникла пароксизмальна гіпертензія: у 1 САТ перевищував 26,7 кПа (200 мм рт. ст.), у 1 гіпертонічний криз змінився стійкою гіпотонією - САТ понад 26,7 кПа (200 мм рт. ст.) знизився до рівня менше 10,7 кПа (80 мм рт. ст.). У 3 (18,75\%) пацієнтів на фоні підвищеного артеріального тиску - 20,0 - 24,0 кПа (150 - 180 мм рт. ст.) - під час ЛА виникла стійка гіпотонія - САТ менше 10,7 кПа (80 мм рт. ст.). У 1-й групі змін САТ не спостерігали $(\mathrm{p}=0,006)$.

Ніхто із пацієнтів обох груп не помер. Ускладнення виникли у 2 (12,5\%) пацієнтів 2-ї групи: у 1 - порушення мозкового кровообігу за типом ішемії в басейні лівої передньомозкової артерії (IV ступінь за Clavien-Dindo), у 1 - інфаркт міокарда (IV ступінь за Clavien-Dindo). Обидва хворих після проведеної консервативної терапії і компенсації стану виписані.

Середні строки перебування у стаціонарі після операції пацієнтів 1-ї групи були суттєво менші, ніж 2-ї- (5,9 $\pm 2,2)$ та $(11,3 \pm 5,4)$ дня відповідно $(\mathrm{p}<0,001)$.

\section{Обговорення}

Видалення феохромоцитоми пов'язано зі специфічними ризиками. Одним із серйозних ускладнень, які безпосередньо загрожують життю пацієнта, є СНГ, що виникає через гормональний викид.

На даний момент параметри порушення гемодинаміки, які б у повній мірі характеризували СНГ, не стандартизовані. Так, за даними Американської асоціації анестезіологів та ряду авторів, для СНГ характерні такі гемодинамічні зміни: артеріальна гіпертензія - САТ понад 26,7 кПа (200 мм рт. ст.); артеріальна гіпертензія - САТ понад 26,7 кПа (200 мм рт. ст.), що змінюється гіпотонією - САТ менше 10,7 кПа (80 мм рт. ст.); виражена гіпотонія - САТ менше 10,7 кПа (80 мм рт. ст.) [1, 8]. Інші дослідники, зокрема L. Bruno і співавтори, визначали СНГ у разі підвищення САТ понад 21,4 кПа (160 мм рт. ст.) [3].

Для профілактики розвитку СНГ рекомендують проводити передопераційну медикаментозну підготовку, що включає призначення препаратів $\alpha$ - та $\beta$-адреноблокаторів, інгібіторів ангіотензинперетворюючого ферменту в поєднанні зі збагаченою сіллю дієтою за 7 - 14 днів до оперативного втручання [9]. Ряд авторів вважають доцільним подовжити цей термін до 2 - 6 тиж [10]. Втім, ці заходи не завжди дають змогу уникнути гормон-асоційованих порушень гемодинаміки під час операції [4, 11]. Так, F. Berends і співавтори під час мобілізації надниркової залози зафіксували виникнення гіпертензії, за якої САТ дорівнював 24,0 - 28,0 кПа (180 - 210 мм рт. ст.), у 26\% пацієнтів 3 феохромоцитомою, хоча їм виконували попередню альфа-адренергічну блокаду [12]. Дані нашого дослідження показали, що, незважаючи на виконану передопераційну альфа-адренергічну блокаду, у 2-й групі інтраопераційні гіпертензивні епізоди зафіксовані у 31,25\% пацієнтів.

За даними літератури частота ускладнень у періопераційному періоді внаслідок гормонального викиду становить $8-17 \%[1,3]$, летальність, причинами якої $€$ інфаркт міокарда, інсульт, тромбоемболія легеневої артерії, катехоламіновий шок, набряк легенів, головного мозку - 2,4 - 3\% [13]. Ми спостерігали ускладнення тільки у 2-й групі хворих, ї частота становила 12,5\%.

Отже, пошук оптимального способу профілактики розвитку СНГ безумовно $є$ актуальним.

Ендоваскулярні втручання у хворих з патологією наднирників широко застосовували у 70 - 90-х рр. Особливе місце в інтервенційній радіології займає трансартеріальна емболізація (ТАE) наднирника, яку вперше використали Н. Bunuan і співавтори [14]. Вони виконали у пацієнта емболізацію артерій наднирника хірургічним желатином (Gelfoam) за 24 год до оперативного втручання 3 метою пригнічення активності функціонуючої феохромоцитоми. Пізніше J. Horton і співавтори [15] повідомили про успішну ТАЕ в комбінованому лікуванні функціонуючої феохромоцитоми. ТАЕ також застосовували як альтернативний метод лікування для пригнічення гормональної активності у разі іншої патології наднирників, зокрема, S. Blunt і співавтори - при синдромі Кушинга [16], F. O'Keeffe і співавтори - при гіперсекретуючому кортизоладренокортикальному раку [17], H. Hokotta і співавтори - при альдостеромі [18]. Як емболізуючі матеріали застосовували Gelfoam [14], полівініловий спирт та Gelfoam [17], етанол - іогексол та сталеві спіралі $[16,18]$.

Досі ТАЕ не втратила своєї актуальності, ії використовують для пригнічення активності функціонуючої пухлини надниркової залози, профілактики виникнення кровотечі під час оперативного втручання, а також зменшення розміру пухлини і больового синдрому [19 - 22]. Так, M. Нabib і співавтори виконували ТАЕ наднирника, використовуючи сталеві спіралі, для зупинки кровотечі внаслідок спонтанного розриву феохромоцитоми і профілактики виникнення кровотечі під час оперативного втручання $[19,20]$. Є повідомлення про застосування ТАЕ над- 
нирника полівініловим спиртом для пригнічення гормональної активності пухлини під час підготовки пацієнтів до адреналектомії [22, 23].

Як правило, пацієнти переносять ТАЕ добре, а виникнення больового синдрому (від легкого до помірного тривалістю менше 48 год) та субфебрильної температури тіла корегують консервативно $[17,22]$. Окремі автори спостерігали і більш тяжкі ускладнення: розвиток гіпертензіі та тахікардії внаслідок емболізації надниркових артерій, рефлюкс емболізату в сусідні артерії $[18,22]$. H. Hokotta i співавтори повідомили про параліч нижніх кінцівок через випадкову емболізацію передньої спинальної артерії під час емболізації артерії надниркової залози [18].

Для ТАЕ наднирника використовують безліч різних емболічних матеріалів, проте через ретроградний кровоток або їх міграцію жоден з цих матеріалів не виявився ідеальним для виконання суперселективної оклюзії вен наднирників з метою попередження викиду гормонів у загальний кровоток [24, 25]. Так, J. Doppman та M. Girton у дослідженнях на тваринах встановили, що ретроградне введення абсолютного етанолу в ЦВН - неефективний та небезпечний спосіб абляції наднирника [24]. Більше того, воно призводило до вивільнення запасів катехоламінів навіть 3 патологічно незмінених наднирників.

Вивчення нами рівня метанефрину продемонструвало достовірне його зменшення у пацієнтів після РЕВСЕО судин наднирника, що свідчить про пригнічення гормональної активності пухлини. Клінічний перебіг та показники гемодинаміки в інтраопераційному періоді вказували на зменшення ризику розвитку СНГ після попереднього застосування РЕВСЕО. Це дає нам підстави вважати успішну РЕВСЕО судин наднирника альтернативою ранній перев'язці ЦВН під час операції як ключового фактора зниження ризику надмірної секреції гормонів надниркової залози.

\section{Висновки}

Застосування мультидисциплінарного підходу в лікуванні феохромоцитом приводить до зменшення об'єму крововтрати та запобігає розвитку СНГ і пов'язаних із ним ускладнень.

\section{References}

1. Kiernan C, Fan K, Broome J, Shi C, Peters M, Solorzano C. Predictors of Hemodynamic Instability During Surgery for Pheochromocytoma. Journal of Surgical Research. 2014;186 (2):556. doi 10.1245 / s10434 014-3847-7.

2. Lee J, El-Tamer M, Schifftner T, Turrentine FE, Henderson WG, Khuri S, et al. Open and laparoscopic adrenalectomy: analysis of the National Surgical Quality Improvement Program. Journal of the American College of Surgeons. 2008;206(5):953-959. discussion 9-61. doi: 10.1016/j.jamcollsurg.2008.

3. Bruno L, Nguyen-Thi P, Mirallie E, Raffaelli M, Vriens M, Theveniaud $\mathrm{P}$, et al. Predictive factors for postoperative morbidity after laparoscopic adrenalectomy for pheochromocytoma: a multicenter retrospective analysis in 225 patients. Surgical Endoscopy. 2015;30(3):1051-9. doi 10.1007/s00464-015-4294-7.

4. Goers T, Abdo M, Moley J, Matthews B, Quasebarth M, Brunt L. Outcomes of the resection of extra-adrenal pheochromocytoma / paragangliomas in the laparoscopic era: a comparison with adrenal pheochromocytoma. Surgical Endoscopy. 2012;27(2):428-33. doi 10.1007/s00464012-2451-9.
5. Gaujoux S, Bonnet S, Lentschener C, Thillois J, Duboc D, Bertherat J, et al. Preoperative risk factors for hemodynamic instability during laparoscopic adrenalectomy for pheochromocytoma. Surgical Endoscopy. 2015;30(7):2984-93. doi 10.1007/s00464-015-4587-x.

6. Elfenbein D, Scarborough J, Speicher P, Scheri R. Comparison of laparoscopic versus open adrenalectomy: results from the American College of Surgeons-National Surgery Quality Improvement Project. Journal of Surgical Research. 2013;184(1):216-20. doi: 10.1016/j.jss.2013.04.014.

7. Conzo G, Tartaglia E, Gambardella C, Esposito D, Sciascia V, Mauriello $\mathrm{C}$, et al. Minimally invasive approach to adrenal lesions: A systematic review of laparoscopic versus retroperitoneoscopic adrenalectomy and assessment of risk factors for complications. International Journal of Surgery. 2016;28:118-23. doi: 10.1016/jpy.2015.12.042.

8. Randle R, Balentine C, Pitt S, Schneider D, Sippel R. Selective Versus Non-selective $\alpha$-Blockade Prior to Laparoscopic Adrenalectomy for Pheochromocytoma. Annals of Surgical Oncology. 2016;24(1):244-50. doi 10.1245/s10434-016-5514-7.

9. Lenders J, Duh Q, Eisenhofer G, Gimenez-Roqueplo A, Grebe S, Murad M, et al. Pheochromocytoma and Paraganglia: An Endocrine Society Clinical Practice Guideline. The Journal of Clinical Endocrinology \& Metabolism. 2014;99(6):1915-42. doi: 10.1210/jc.2014-1498.

10. Fishbein L, Orlowski R, Cohen D. Pheochromocytoma / Paraganglioma: Review of Perioperative Management of Blood Pressure and Update on Genetic Mutations Associated With Pheochromocytoma. The Journal of Clinical Hypertension. 2013;15(6):428-434. doi: 10.1111/jch.12084.

11. Challis B, Casey R, Simpson H, Gurnell M. Is there an optimal preoperative management strategy for phaeochromocytoma / paraganglioma ?. Clinical Endocrinology. 2016;86(2):163-7. doi: 10.1111/cen.13252.

12. Berends FJ, Harst EV, Giraudo G, Terkivatan T, Kazemier G, Bruining HA, et al. Safe retroperitoneal endoscopic resection of pheochromocytomas. World J Surg. 2002 May;26(5):527-31. doi: 10.1007/s00268001-0261-7.

13. Lenders JWM, Eisenhofer G, Mannelli M, Pacak K. Phaeochromocytoma. Lancet. 2005;366:665-75.

14. Bunuan H, Alltree M, Merendino K. Gel foam embolization of a functioning feochromocytoma. The American Journal of Surgery. 1978;136(3):395-8.

15. Horton J, Hrabovsky E, Klingberg W, Hostler J, Jenkins J. Therapeutic embolization of hyperfunctioning pheochromocytoma. American Journal of Roentgenology. 1983;140(5):987-8.

16. Blunt S, Firsthand M, Chatterjee V, Burrin J, Allison D, Joplin G. Use of adrenal arterial embolization in severe ACTH-dependent Cushing's syndrome. Postgraduate Medical Journal. 1989;65(766):575-9.

17. O'Keeffe F, Carrasco C, Charnsangavej C, Richli W, Wallace S. Arterial embolization of adrenal tumors: results in nine cases. American Journal of Roentgenology. 1988;151(4): 819-22.

18. Hokotta H, Inoue H, Baba Y, Tsuchimochi S, Nakajo M. Aldosterone: Experience with Superselective Adrenal Arterial Embolization in 33 Cases. Radiology. 2003;227(2):401-6.

19. Habib M, Tarazi I, Batta M. Arterial embolization for ruptured adrenal pheochromocytoma. Current Oncology. 2010;17(6).

20. Park J, Kang K, Lee S, Kim C, Park T, Baek H. A case of a Ruptured Pheochromocytoma with an Intratumoral Aneurysm Managed by Coil Embolization. Endocrine Journal. 2003;50(6):653-6.

21. Pua U. Trans-arterial embolization of spontaneous adrenal pheochromocytoma rupture using polyvinyl alcohol particles. Singapore medical journal. 2008. https://www.researchgate.net/publication/5386678.

22. Wannachalee T, Buranagan R. Successful Preoperative Transcatheter Arterial Embolization of a Large Malignant Pheochromocytoma to Decrease Intraoperative Blood Loss. Endocrine Society's 97th Annual Meeting and Expo, March 5-8, 2015 - San Diego. - 2015 http://press.endocrine.org/doi/abs/10.1210/endo-meetings.2015.AHPAA.15.FRI-403.

23. Pua U. Trans-arterial embolization of spontaneous adrenal pheochromocytoma rupture using polyvinyl alcohol particles. Singapore medical journal. 2008. https://www.researchgate.net/publication/5386678.

24. Doppman J, Girton M. Adrenal ablation by retrograde venous ethanol injection: an ineffective and hazardous procedure. Radiology 1984;150(3):667-72.

25. Lecky J. Adrenal Ablation Functionalizing Angiographic Catheter. JAMA: The Journal of the American Medical Association. $1971 ; 218(9): 1438$. 